\title{
PENGARUH MOTIVASI DAN DISIPLIN KERJA TERHADAP KINERJA KARYAWAN BALAI MONITOR SPEKTRUM FREKUENSI RADIO KELAS II PADANG
}

\author{
Usmiar $^{1}$ Rian Utomo ${ }^{2}$ \\ Universitas Muhammadiyah Sumatera Barat \\ usmiar@umsb.ac.id
}

\begin{abstract}
The purpose of this study was to determine the effect of motivation, work discipline on employee performance at the Class II Radio Frequency Spectrum Monitoring Center, Padang. The research sample consisted of 35 respondents using total sampling method. The study used multiple linear regression analysis and hypothesis testing with the T test and $F$ test.

The results of the discussion turned out that motivation (X1), work discipline (X2) had a significant effect on employee performance, the value of Fcount was 3.195> Ftable 2.51. And the second result, motivation has a significant effect on employee performance tcount 2.068> ttable 2.037, work discipline has no significant effect on employee performance tcount 1.040 $<$ ttable 2.037. The coefficient of determination (R2) is 0.408 or $40.8 \%$, which indicates that the percentage of contribution to the influence of motivation and work discipline on employee performance, while the remaining $59.2 \%$ is explained by other variables not included in this research model.
\end{abstract}

Keywords: Balai Monitor, Total Sampling and Regression Analysis

Abstrak : Tujuan penelitian ini adalah untuk mengetahui pengaruh motivasi, disiplin kerja terhadap kinerja karyawan pada Balai Monitor Spektrum Frekuensi Radio Kelas II Padang. Sampel penelitian ini berjumlah 35 responden dengan menggunakan metode total sampling. Penelitian menggunakan analisis regresi linear berganda dan pengujian hipotesis dengan uji $\mathrm{T}$ dan uji F.

Hasil pembahasannya ternyata motivasi $\left(\mathrm{X}_{1}\right)$, disiplin kerja $\left(\mathrm{X}_{2}\right)$ berpengaruh signifikan terhadap kinerja karyawan, nilai $\mathrm{F}_{\text {hitung }} 3,195>\mathrm{F}_{\text {tabel }} 2$ 2,51. Dan hasil yang kedua motivasi berpengaruh signifikan terhadap kinerja karyawan $t_{\text {hitung }} 2,068>t_{\text {tabel }} 2,037$, disiplin kerja tidak berpengaruh signifikan terhadap kinerja karyawan $t_{\text {hitung }} 1,040<t_{\text {tabel }} 2,037$. Nilai koefisien determinasi $\left(\mathrm{R}^{2}\right)$ sebesar 0,408 atau 40,8\% yang menunjukkan bahwa persentase sumbangan pengaruh motivasi dan disiplin kerja terhadap kinerja karyawan, sedangkan sisanya sebesar 59,2 $\%$ dijelaskan oleh variabel lain yang tidak dimasukkan dalam model penelitian ini.

Kata kunci : Balai Monitor, Total Sampling dan Analisis Regresi

\section{A. PENDAHULUAN}

\subsection{Latar Belakang Masalah}

Salah satu aspek yang paling sulit dihadapi manajemen pada seluruh organisasi saat ini adalah bagaimana membuat karyawan mereka bekerja secara efisien. Pada hakekatnya sumber daya manusia merupakan salah satu modal dan memegang peranan penting dalam keberhasilan perusahaan atau instansi. Manusia merupakan penggerak dan penentu jalannya suatu organisasi atau instansi. Karena pentingnya unsur manusia dalam menjalankan suatu pekerjaaan maka perlu mendapatkan perhatian dari pimpinan. Karyawan merupakan faktor penting dalam setiap organisasi baik dalam pencapaian tujuan organisasi atau perusahaan secara efektif dan efisien. Suatu organisasi bukan hanya mengharapkan karyawan yang mampu, cakap, dan terampil, tetapi yang terpenting mereka mau bekerja giat dan berkeinginan untuk mencapai hasil kerja yang maksimal.

Salah satu cara yang digunakan untuk melihat perkembangan perusahaan adalah dengan cara melihat hasil kinerja karyawan. Sasaran yang menjadi objek kinerja adalah kecakapan, dan kemampuan karyawan dalam melaksanakan suatu pekerjaan atau tugas yang di evaluasi dengan menggunakan tolak ukur tertentu yang dilakukan scara objektif dan secara berkala. 
Kinerja didalam suatu organisasi dilakukan oleh segenap sumber daya manusia didalam organisasi,baik unsur pimpinan maupun pekerja. Banyak sekali yang mempengaruhi sumber daya manusia dalam menjalankan kinerjanya, setiap pekerja mempunyai kemampuan berdasarkan pada pengetahuan dan keterampilan, kompetensi yang sesuai dengan pekerjaannya namun pekerja juga mempunyai kepribadian, sikap, prilaku yang dapat mempengaruhi kinerjanya.

Dari hasil penilaian dapat dilihat kinerja perusahaan yang dicerminkan oleh kinerja karyawan atau dengan kata lain, kinerja merupakan hasil kerja kongkret yang dapat diamati dan dapat diukur.

menurut Fathoni (2006:126) Kedisiplinan adalah kesadaran dan kesediaan seseorang mentaati semua peraturan perusahaan dan norma-norma sosial yang berlaku.

Dari defenisi disiplin kerja diatas dapat disimpulkan bahwa disiplin kerja merupakan prilaku seseorang sesuai dengan peraturan, prosedur kerja yang ada.

Kedisiplinan merupakan fungsi opertif MSDM yang terpenting. Semakin baik disiplin karyawan pada sebuah perusahaan, semakin tinggi prestasi kerja yang dapat dicapai. Sebaliknya, tanpa disiplin karyawan yang baik, sulit bagi perusahaan mencapai hasil yang optimal.

Disiplin yang baik mencerminkan besarnya tanggung jawab seseorang terhadap tugas-tugas yang diberikan kepadanya. Hal ini mendorong gairah kerja, semangat kerja, dan terwujudnya tujuan peerusahaan, karawan serta masyarakat pada umumnya. Melalui disiplin akan mencerminkan kekuatan, karena biasanya seseorang yang berhasil dalam karyanya, studynya biasanya adalah mereka yang memiliki disiplin yang tinggi seorang yang sehat dan kuat biasanya pun memiliki disiplin yang baik, dalam arti ia mempunyai keterattuan didalam menjaga dirinya, teratur kerja, teratur makan tertib olahraga, dan tertib dalam segala hal.

Keberhasilan suatu kantor juga dapat dilihat dari kemampuannya dalam meningkatkan kinerja kantor yang mana hal itu dapat dicapai tergantung pada kinerja karyawan. Melihat pentingnya motivasi dan disiplin kerja bagi peningkatan kinerja para karyawan, maka dalam hal ini Balai Monitor Spektrum Frekuensi Radio Kelas II Padang juga perlu memperhatikan hal tersebut agar dapat meningkatkan kinerja para karyawannya. Agar lebih ditingkatkan lagi motivasi dan disiplin karyawan maka pihak kantor harus lebih mendorong semangat para karyawan agar bekerja lebih baik lagi, dan bagi karyawan yang tidak disiplin pihak kantor harus memberi sanksi yang lebih kuat agar karyawan tidak semena-mena.

Dengan melihat kedua faktor tersebut yaitu motivasi dan disiplin kerja merupakan aspek penting dalam membangkitkan kinerja karyawan. Akan menciptakan suatu iklim kerja yang kondusif sehingga dapat bersinergi dengan meningkatkan semangat atau kegairahan kerja karyawan untuk mencapai tujuan organisasi, khususnya pada Balai Monitor Spektrum Frekuensi Radio Kelas II Padang. Kemudian timbul pemikiran bagaimana keseluruhan faktor tersebut saling berkesinambungan sehingga mempengaruhi kinerja karyawan. Berdasarkan uraian di atas maka perlu dilakukan penelitian dengan judul: "Pengaruh Motivasi dan Disiplin kerja terhadap Kinerja Karyawan Pada Balai Monitor Spektrum Frekuensi Radio Kelas II Padang ”.

\subsection{Rumusan Masalah}

Berdasarkan uraian di atas, dapat diajukan perumusan masalah sebagai berikut :

1. Apakah motivasi berpengaruh terhadap kinerja karyawan pada Balai Monitor Spektrum Frekuensi radio Kelas II Padang?

2. Apakah disiplin kerja berpengaruh terhadap kinerja karyawan pada Balai Monitor Spektrum Frekuensi radio Kelas II Padang?

3. Apakah motivasi dan disiplin kerja berpengaruh terhadap kinerja karyawan Balai Monitor Spektrum Frekuensi radio Kelas II Padang?

\subsection{Tujuan Penelitian}

1. Untuk mengetahui dan menganalisis pengaruh motivasi terhadap kinerja karyawan pada Balai Monitor Spektrum Frekuensi radio Kelas II Padang.

2. Untuk mengetahui dan menganalisis pengaruh disiplin kerja terhadap kinerja karyawan pada Balai Monitor Spektrum Frekuensi radio Kelas II Padang. 
3. Untuk mengetahui pengaruh dan menganalisis motivasi dan disiplin kerja terhadap kinerja karyawan pada Balai Monitor Spektrum Frekuensi radio Kelas II Padang.

\section{B. TINJAUAN PUSTAKA}

2.1 Kinerja

\subsubsection{Pengertian kinerja}

Menurut Wibowo (2014:70) Kinerja adalah suatu proses tantangan bagaimana pekerjaan berlangsung untuk mencapai hasil kerja. Menurut Rivai (2011:604) menyatakan kinerja adalah suatu tampilan keadaan secara utuh atas perusahaan selama priode waktu tertentu, merupakan hasil atau prestasi yang dipengaruhi oleh kegiatan operasional perusahaan dalam memanfaatkan sumber-sumber daya yang dimiliki. Sedangkan menurut Kasmir (2016:481) Kinerja adalah hasil kerja yang dapat dicapai oleh seorang atau sekelompok orang dalam suatu organisasi sesuai wewenang dan tanggung jawab masing-masing dalam rangka mencapai tujuan organisasi secara legal, tidak melanggar hukum dan sesuai etika. Menurut Mangkunegara (2013:67) kinerja adalah hasil kerja secara kualitas dan kuantitas yang dicapai oleh seorang pegawai dalam melaksanakan tugasnya sesuai dengan tanggung jawab yang diberikan kepadanya.

Dari defenisi kinerja diatas dapat disimpulkan bahwa kinerja karyawan merupakan perilaku nyata yang ditampilkan setiap orang sebagai prestasi kerja yang dihasilkan oleh karyawan sesuai dengan perannya dalam perusahaan. Kinerja yang baik adalah kinerja yang optimal, yaitu kinerja yang sesuai standar organisasi dan mendukung tercapainya tujuan organisasi.

\subsubsection{Faktor-faktor yang mempengaruhi kinerja}

Menurut Sugiyono (dalam Riduwan, 2002:135) kinerja seseorang dipengaruhi oleh beberapa faktor diantaranya ialah: latihan, pengalaman kerja, pendidikan, sikap kepribadian, organisasi, kepemimpinan, kondisi sosial, kebutuhan individu, kondisi fisik, tempat kerja, kemampuan, motivasi dan sebagainya.

Menurut Robbins (2006:121) kinerja karyawan merupakan pengukuran terhadap hasil kerja yang diharapkan berupa sesuatu yang optimal. Faktor-faktor yang mempengaruhi kinerja adalah sebagai berikut:

a. Pendidikan

Pendidikan adalah pembelajaran pengetahuan, keterampilan, dan kebiasaan sekelompok orang yang diturunkan dari satu generasi ke generasi selanjutnya melalui pengajaran, pelatihan atau penelitian.

b. Keterampilan

Keterampilan adalah kemampuan menggunakan akal, fikiran, ide dan kreatifitas dalam mengerjakan, mengubah ataupun membuat sesuatu menjadi lebih bermakna sehingga menghasilkan nilai dari hasil pekerjaan.

c. Iklim organisasi

Iklim kerja dalam suatu organisasi sangatlah penting bagi pimpinan untuk memahami kondisi organisasi, karena ia harus menyalurkan bawahan sehingga mereka dapat mencapai tujuan pribadi dan tujuan organisasi. Dengan adanya iklim kerja yang kondusif, maka hal itu akan mempengaruhi kinerja karyawan.

d. Kepemimpinan

Peranan pemimpin harus mampu dan dapat memainkan peranannya dalam suatu organisasi, pemimpin harus mampu menggali potensi - potensi yang ada pada dirinya dan memanfaatkannya di dalam unit organisasi.

e. Kualitas pekerjaan

Pekerjaan yang dilakukan dengan kualitas yang tinggi dapat memuaskan yang bersangkutan dan perusahaan. Penyelesaian tugas yang terandalkan, tolok ukur minimal kualitas kinerja pastilah dicapai. 
f. Kemampuan kerja

Kemampuan untuk mengatur pekerjaan yang menjadi tanggung jawabnya termasuk membuat jadwal kerja, umumnya mempengaruhi kinerja seorang karyawan.

g. Inisiatif

Inisiatif merupakan faktor penting dalam usaha untuk meningkatkan kinerja karyawan. Untuk memiliki inisiatif dibutuhkan pengetahuan serta ketrampilan yang dimiliki para karyawan dalam usaha untuk meningkatkan hasil yang dicapainya.

h. Motivasi

Motivasi ini merupakan subyek yang penting bagi pimpinan, karena menurut definisi pimpinan harus bekerja dengan dan melalui orang lain. Pimpinan perlu memahami orang - orang berperilaku tertentu agar dapat mempengarhuinya untuk bekerja sesuai dengan yang diinginkan perusahaan.

i. Daya tahan/ kehandalan

Apakah karyawan mampu membuat perencanaan dan jadwal pekerjaannya. Sebab akan mempengaruhi ketepatan waktu hasil pekerjaan yang menjadi tanggung jawab seorang karyawan.

j. Kuantitas pekerjaan

Pekerjaan yang dilakukan karyawan harus memiliki kuantitas kerja tinggi dapat memuaskan yang bersangkutan dan perusahaan.

k. Disiplin kerja

Dalam memperhatikan peranan manusia dalam organisasi, agar dapat mencapai tujuan yang ditentukan diperlukan adanya kedisiplinan yang tinggi sehingga dapat

\subsection{Motivasi} mencapai suatu hasil kerja yang optimal atau mencapai hasil.

\section{Pengertian Motivasi}

Sinambela (2006:165) Motivasi menurut arti katanya motivasi atau motivation berarti pemberian motif, penimbulan motif atau hal yang menimbulkan dorongan atau keadaan yang menimbulkan dorongan. Motivasi dapat juga diartikan faktor yang mendorong orang untuk bertindak dengan cara tertentu. Menurut Rivai (2011:837) Motivasi adalah Serangkaian sikap dan nilai-nilai yang mempengaruhi individu untuk mencapai hal yang spesifik sesuai dengan tujuan individu. Menurut Mangkunegara (2013:94) Motivasi adalah kondisi suatu energi yang menggerakkan diri karyawan yang terarah atau tertuju untuk mencapai tujuan organisasi perusahaan. Sikap mental karyawan yang pro dan positif terhadap situasi kerja itulah yang memperkuat motivasi kerjanya untuk mencapai kinerja maksimal. Artinya karyawan dalam bekerja harus siap secara mental, fisik, sehat, memahami situasi dan kondisi serta berusaha keras mencapai target kerja yakni tujuan utama organisasi.

Dari pengertian motivasi diatas dapat disimpulkan bahwa motivasi merupakan dorongan terhadap serangkaian proses prilaku manusia pada pencapaian tujuan.

Pada hakikatnya tujuan pemberian motivasi kepada para karyawan adalah

a. Mengubah prilaku karyawan sesuai dengan keinginan perusahaan.

b. Meningkatkan gairah dan semangat kerja.

c. Meningkatkan disiplin kerja.

d. Meningkatkan prestasi kerja.

e. Mempertinggi moral kerja karyawan.

f. Meningkatkan rasa tanggung jawab.

g. Meningkatkan produktifitas dan efisiensi.

h. Menumbuhkan loyalitas karyawan pada perusahaan

\subsection{Disiplin Kerja \\ Pengertian disiplin}

Menurut Rivai (2011:825) Disiplin kerja adalah suatu alat yang digunakan para manajer untuk berkomunikasi dengan karyawan agar mereka bersedia untuk mengubah suatu prilaku serta sebagai suatu upaya untuk meningkatkan kesadaran dan kesediaan seseorang mentaati 
semua peraturan perusahaan dan norma-norma sosial yang berlaku. Menurut Hamali (2016:214) Disiplin kerja adalah suatu kekuatan yang berkembang didalam tubuh karyawan dan menyebabkan karyawan dapat menyesuaikan diri dengan sukarela pada keputusan peraturan dan nilai-nilai tinggi dari pekerjaan dan prilaku. Sedangkan menurut Fathoni (2006:126) Kedisiplinan adalah kesadaran dan kesediaan seseorang mentaati semua peraturan perusahaan dan norma-norma sosial yang berlaku.

Dari defenisi disiplin kerja diatas dapat disimpulkan bahwa disiplin kerja merupakan prilaku seseorang sesuai dengan peraturan, prosedur kerja yang ada.

\section{METODE PENELITIAN}

\subsection{Jenis Penelitian}

Pada penelitian ini jenis penelitiannya adalah penelitian Deskriptif. Penelitian Deskripti menurut Sugiyono (2017:35) adalah Metode penelitian deskriptif ini dilakukan untuk mengetahui keberadaan variabel mandiri, baik hanya saat variabel atau lebih (variabel yang berdiri sendiri atau variabel bebas) tanpa membuat perbandingan variabel itu sendiri dan mencari hubungan dengan variabel lain.

\subsection{Tempat dan Waktu Penelitian}

Tempat penelitian ini dilakukan pada Balai Monitor Spektrum Frekuensi Radio Kelas II Padang yang beralamat Jl. Pulai Batang Kabung Kel. Batang Kabung, Kec.Koto Tangah Padang. Penelitian ini dilakukan pada bulan April 2019.

\subsection{Populasi dan Sampel}

\subsubsection{Populasi}

Menurut Sugiyono (2017:80) Populasi diartikan sebagai wilayah generalisasi yang terdiri atas objek atau subjek yang mempunyai kualitas dan karakteristik tertentu yang ditetapkan oleh peneliti untuk dipelajari dan kemudian ditarik kesimpulannya. Populasi pada penelitian ini yaitu seluruh karyawan pada Balai Monitor Spektrum Frekuensi Radio Kelas II Padang bagian yang berjumlah 35 orang.

\subsubsection{Sampel}

Teknik pengambilan sampel yang digunakan dalam penelitian ini adalah teknik total sampling. Menurut Sugiyono (2017:81) Dalam penelitian kuantitatif sampel adalah bagian dari jumlah dan karakteristik yang dimiliki oleh populasi tersebut. Sampel pada penelitian ini adalah seluruh karyawan pada Balai Monitor Spektrum Frekuensi Radio Kelas II Padang yang berjumlah 35 Orang.

\subsection{Teknik Analisis Data}

\subsubsection{Statistic Deskriptif}

Menurut Sugiyono (2017:147) Statistik deskriftif adalah metode statistik yang digunakan untuk menganalisis data dengan cara mendeskripsikan atau menggambar data yang telah terkumpulkan sebagaimana adanya tanpa bermaksud membuat kesimpulan yang berlaku untuk umum atau generalisasi. Analisis statistic deskriptif digunakan untuk mendiskripsikan responden, nilai rata-rata variabel kinerja karyawan, motivasi dan disiplin kerja karyawan serta distribusi frekuensi jawaban responden terhadap masing-masing pertanyaan pada variabel penelitian.

\subsubsection{Uji Hipotesis}

Uji hipotesis digunakan untuk melihat kontribusi variabel $\mathrm{X} 1$ terhadap variabel $\mathrm{Y}$ dan variabel X2 terhadap Y. Uji hipotesis dalam penelitian ini dikelompokkan atas dua cara yaitu:

\section{a. Secara Parsial (Uji T-test)}

Uji t dilakukan untuk membuktikan secara empiris signifikan atau tidaknya pengaruh variabel bebas (X1) dan (X2) terhadap variabel terikat (Y). Uji t digunakan untuk mengetahui 
variabel independen mana yang paling signifikan hubungannya dengan variabel dependen secara individual untuk menghitung t hitung digunakan rumus sebagai berikut:

$$
\mathrm{t}=\frac{r \sqrt{n-2}}{\sqrt{1-r^{2}}}
$$

apabila $\mathrm{t}$ hitung $<\mathrm{t}$ tabel maka Ho diterima. Untuk mengetahui signifikan konstanta dan signifikan setiap variabel independent maka dilakukan uji t dengan dasar pengambilan keputusan:

Jika probabilitas $>\alpha 0,05$ maka Ho diterima

Jika probabilitas $<\alpha 0,05$ maka Ho ditolak.

b. Secara Simultan (uji F)

Analisis uji $\mathrm{F}$ dilakukan dengan membandingkan nilai $\mathrm{F}$ hitung dengan nilai $\mathrm{F}$ tabel dengan kriteria pengambilan keputusan yaitu:

$\mathrm{F}_{\text {hitung }}<\mathrm{F}_{\text {tabel }}$ : terima Ho, tolak Ho

$\mathrm{F}_{\text {hitung }}>\mathrm{F}_{\text {tabel }}$ : tolak Ho, terima Ha.

\section{c. Koefisien Determinasi $\left(\mathbf{R}^{2}\right)$}

Koefisien determinasi ini bertujuan untuk mengukur seberapa besar persentase kemampuan model penelitian dalam menerangkan pengaruh semua variabel independen terhadap variabel dependen. Koefisien determinasi $\left(\mathrm{R}^{2}\right)$ menunjukkan proporsi yang diterangkan oleh variabel independen dalam model terhadap variabel terikatnya, nilai $\left(\mathrm{R}^{2}\right)$ yang mendekati nilai satu kemampuan variabel independennya memberikan semua informasi yang dibutuhkan untuk memprediksi variabel dependen. Sisanya dijelaskan oleh variabel lain yang tidak dimasukkan dalam model yang keliru.

\section{HASIL DAN PEMBAHASAN}

\subsection{Uji Hipotesis}

\subsubsection{Uji Parsial (Uji t)}

Uji t dilakukan untuk mencari pengaruh variabel bebas terhadap variabel terikat dalam persamaan regresi secara parsial dengan mengasumsikan variabel lain dianggap konstan. Uji t dilakukan dengan membandingkan antara nilai $\mathrm{t}$ yang dihasilkan dari perhitungan statistik dengan $t_{\text {tabel. }}$ Adapun hasil uji t pada penelitian ini dapat dilihat pada tabel berikut:

Tabel 4.17

Hasil Uji t

\begin{tabular}{|c|c|c|c|c|c|}
\hline \multirow[b]{2}{*}{ Model } & \multicolumn{2}{|c|}{$\begin{array}{l}\text { Unstandardized } \\
\text { Coefficients }\end{array}$} & \multirow{2}{*}{$\begin{array}{c}\begin{array}{c}\text { Standardize } \\
\mathrm{d}\end{array} \\
\text { Coefficients } \\
\text { Beta } \\
\end{array}$} & \multirow[b]{2}{*}{$\mathrm{T}$} & \multirow[b]{2}{*}{ Sig. } \\
\hline & B & $\begin{array}{l}\text { Std. } \\
\text { Error }\end{array}$ & & & \\
\hline $1 \quad$ (Constant) & 14,950 & 16,473 & & ,908 &, 371 \\
\hline Motivasi & ,508 & ,246 & ,340 & 2,068 & ,047 \\
\hline $\begin{array}{l}\text { Disiplin } \\
\text { Kerja }\end{array}$ & , 197 & , 189 & ,171 & 1,040 & ,306 \\
\hline
\end{tabular}

a. Dependent Variable: Kinerja Karyawan

Sumber : Hasil Output Spss 2019

Berdasarkan hasil olahan data statistik pada tabel 4.17 maka dapat dilihat pengaruh antara variabel independen terhadap variabel dependen secara parsial adalah sebagai berikut:

1. Hipotesis pertama dalam penelitian ini adalah Motivasi berpengaruh signifikan terhadap Kinerja Karyawan di Balai Monitor Spektrum Frekuensi Radio Kelas II Padang. Terlihat pada tabel 4.17 bahwa nilai signifikan yang dihasilkan 
adalah sebesar $0,047<\alpha 0,05$ maka hipotesis $\left(\mathrm{H}_{1}\right)$ ditolak. Variabel Motivasi mempunyai $\mathrm{t}_{\text {hitung }}$ yakni 2,068 dengan $\mathrm{t}_{\text {tabel }} 2,035$.

2. Hipotesis kedua dalam penelitian ini adalah Disiplin Kerja tidak berpengaruh signifikan terhadap Kinerja Karyawan di Balai Monitor Spektrum Frekuensi Radio Kelas II Padang. Berdasarkan tabel 4.17 bahwa nilai signifikan yang dihasilkan adalah sebesar 0,306 artinya nilai signifikan lebih kecil dari nilai

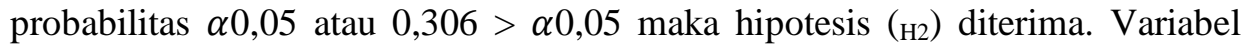
disiplin kerja mempunyai $t_{\text {hitung }}$ yakni 1,040 dengan $t_{\text {tabel }} 2,035$.

\subsubsection{Uji Simultan (Uji F)}

Pengujian ini dilakukan untuk mengetahui semua variabel independen secara bersama-sama (Simultan) dapat berpengaruh terhadap variabel dependen. Hasil dapat dilihat pada tabel berikut:

Tabel 4.18

Hasil Uji Simultan (Uji F)

ANOVA $^{\mathrm{a}}$

\begin{tabular}{|c|c|c|c|c|c|}
\hline Model & Sum of Squares & df & $\begin{array}{c}\text { Mean } \\
\text { Square }\end{array}$ & $F$ & Sig. \\
\hline $\begin{array}{ll}1 & \text { Regressio } \\
\mathrm{n}\end{array}$ & 175,445 & 2 & 87,723 & 3,195 &, $054^{\mathrm{b}}$ \\
\hline Residual & 878,726 & 32 & 27,460 & & \\
\hline Total & 1054,171 & 34 & & & \\
\hline
\end{tabular}

a. Dependent Variable: Kinerja Karyawan

b. Predictors: (Constant), Disiplin Kerja, Motivasi

\section{Sumber : Hasil Output Spss 2019}

Dari tabel 4.18 diatas, dapat dilihat bahwa nilai $F_{\text {hitung }}>F_{\text {tabel }}$ dengan tingkat signifikan $0,054<\alpha 0,01$. Hal ini menunjukkan bahwa terdapat pengaruh yang signifikan secara bersama-sama variabel independen mempengaruhi variabel dependen sebesar 3,195.

\subsubsection{Koefisien Determinasi $\left(\mathbf{R}^{2}\right)$}

Untuk mengetahui besarnya pengaruh dari variabel independen dapat dilihat pada tabel berikut:

Tabel 4.19

\section{Hasil Regresi berganda)}

\section{Model Summary ${ }^{b}$}

\begin{tabular}{|l|c|r|r|r|}
\hline Model & R & R Square & $\begin{array}{c}\text { Adjusted R } \\
\text { Square }\end{array}$ & $\begin{array}{c}\text { Std. Error of } \\
\text { the Estimate }\end{array}$ \\
\hline 1 &, $408^{\mathrm{a}}$ &, 166 &, 114 & 5,24025 \\
\hline
\end{tabular}

a. Predictors: (Constant), Disiplin Kerja, Motivasi

b. Dependent Variable: Kinerja Karyawan

\section{Sumber : Hasil Output Spss 2019}

Dari tabel 4.19 diatas dapat diperoleh nilai $\mathrm{R}$ sebesar 0,408. Hal ini menunjukkan bahwa terjadi hubungan yang sedang antara Motivasi dan Disiplin Kerja terhadap Kinerja Karyawan. Sedangkan untuk R square didapat sebesar 0,166 atau $(16,6 \%)$. Hal ini menunjukkan bahwa presentase sumbangan pengaruh variabel independen (Motivasi dan Disiplin Kerja) terhadap variabel dependen (Kinerja Karyawan) sebesar 16,6\% atau variabel variasi independen yang digunakan dalam model (Motivasi dan Disiplin Kerja) mampu menjelaskan sebesar 16,6\% variasi variabel dependen (Kinerja Karyawan), sedangkan sisanya sebesar 83,4 \% dipengaruhi atau dijelaskan oleh variabel lain yang tidak dimasukkan dalam penelitian ini. 


\section{E. PENUTUP}

\subsection{Kesimpulan}

Berdasarkan hasil penelitian dan pembahasan dapat diambil beberapa simpulan antara lain:

1. Motivasi berpengaruh signifikan terhadap Kinerja Karyawan pada Balai Monitor Spektrum Radio Kelas II Padang. Ditujukan dari hasil uji secara parsial (uji t) diperoleh $\mathrm{t}_{\text {hitung }}$ sebesar 2,068 dan $\mathrm{t}_{\text {tabel }}$ 2,037 dengan nilai sinifikan 0,047 artinya $0,047<\alpha 0,05$. Hal ini berarti bahwa motivasi mempunyai pengaruh yang positif terhadap signifikan kinerja karyawan. Dengan demikian hipotesis $\left(\mathbf{H}_{1}\right)$ diterima.

2. Disiplin Kerja tidak berpengaruh signifikan terhadap Kinerja Karyawan pada Balai Monitor Spektrum Frekuensi Radio Kelas II Padang. Ditujukan dari hasil uji secara parsial (uji $t$ ) diperoleh $t_{\text {hitung }}$ sebesar 1,040 dan $t_{\text {tabel }} 2,037$ dengan nilai signifikan 0,306 artinya $0,306>\alpha 0,05$. Hal ini berarti bahwa disiplin kerja mempunyai pengaruh yang negatif terhadap signifikan kinerja karyawan. Dengan demikian hipotesis $\left(\mathrm{H}_{2}\right)$ ditolak.

3. Motivasi dan disiplin kerja jika di uji secara bersama nilai $F_{\text {hitung }}$ sebesar 3,195 dengan $F_{\text {tabel }}$ sebesar 2,51 sehingga $F_{\text {hitung }}>F_{\text {tabel }}$ dengan tingkat signifikannya $0,054>\alpha 0,05$. Hal ini berarti bahwa terdapat pengaruh yang signifikan secara bersama-sama antara semua variabel bebas terhadap variabel terikat. Dapat disimpulkan bahwa model ini layak di uji.

\subsection{Saran}

Dari hasil pembahasan serta kesimpulan diatas, maka penulis memberikan saran kepada Balai Monitor Spektrum Frekuensi Radio Kelas II Padang semoga bermanfaat bagi masa mendatang. Adapun saran yang penulis berikan adalah sebagai berikut :

1. Dilihat dari hasi uji $t$ (uji secara parsial) Disiplin Kerja berpengaruh secara signifikan terhadap Kinerja Karyawan Pada Balai Monitor Spektrum Frekuensi Radio Kelas II Padang, maka sebaiknya Balai Monitor Spektrum Frekuensi Radio Kelas II Padang mempertahankanserta meningkatkan lagi disiplin kerja karyawan agar lebih disiplin dan peraturan yang telah dijalankan.

2. Dilihat dari uji $F$ ( uji secara simultan) Motivasi dan Disiplin Kerja tidak bersamaan berpengaruh signifikan terhadap Kinerja Karyawan pada Balai Monitor Spektrum Frekuensi Radio Kelas II Padang agar mempertahankan dan lebih memperhatikan lagi kedua faktor tersebut.

\section{F. DAFTAR PUSTAKA}

Ardansyah dan Wasilawati, (2014). Pengawasan, Disiplin Kerja dan Kinerja Pegawai Badan Pusat Statistik Kabupaten Lampung Tengah. Jurnal Ilmiah, Fakultas Ekonomi Universitas Bandar Lampung.

Arikunto, Suharsimi, (2002). Prosedur Penelitian Suatu Pendekatan Praktek. Jakarta: PT.Rineka Cipta.

Arizona, Dika, Riniwati, Harsuko dan Harahap,Nuddin, (2013). Analisis Pengaruh Gaya Kepemimpinan, Motivasi Kerja dan Komitmen Organisational terhadap Kinerja Pegawai (Studi Pada Dinas Kelutan dan Perikanan Kabupaten Malang). Jurnal Ilmiah, Fakultas Perikanan dan Ilmu Kelautan Universitas Brawijaya.

Fathoni, Abdurrahmat, (2006). Manajemen Sumber Daya Manusia. Cet.1. Jakarta: PT. Rineka Cipta.

Ghozali, Imam, (2013). Aplikasi Analisis Multivariate dengan Program SPSS. Edisi Ketujuh. Semarang: Universitas Diponegoro.

Gomes, Faustino Cardoso, (2001). Manajemen Sumber Daya Manusia. Yogyakarta: Andi Offset. 
Gouzali, Saydam, (2000). Manajemen Sumber Daya Manusia, Suatu Pendekatan Mikro. Jakarta: STIE YKPN.

Hakim, Abdul, (2006). Analisis Pengaruh Motivasi, Komitmen Organisasi dan Iklim Organisasi Terhadap Kinerja Pegawai pada Dinas Perhubungan dan Telemunikasi Provinsi Jawa Tengah. JRBI. 